\title{
Radiological Assessment of Artisanal Gold Mining Sites in Luku, Niger State, Nigeria
}

\author{
Sabo A*, Sadiq L. S., Gamba J. \\ Department of Environmental Management Technology, Faculty of Environmental Technology, \\ Abubakar Tafawa Balewa University, PMB 0248, Bauchi, Bauchi State, Nigeria \\ *Corresponding author: saboa2000@yahoo.com
}

\begin{abstract}
Artisanal small scale mining of solid minerals has the potential of causing many environmental and health problems. Thus, assessment of ionizing radiation in vulnerable areas is very important from the environmental health point of view. This study was aimed at determining the level of radiation in the vicinity of artisanal gold mining sites in Luku, Niger State, Nigeria. Measurements were made at four different Stations: A, B, C and D using Radiation Inspector Alert meter (EXP ${ }^{+}$model). The investigation revealed that mean values of $1.66 \mathrm{mSv} / \mathrm{yr}, 1.55$, $\mathrm{mSv} / \mathrm{yr}, 1.48 \mathrm{mSv} / \mathrm{yr}$ and $2.12 \mathrm{mSv} / \mathrm{yr}$ were recorded for stations A, B, C and D respectively. The radiation levels recorded from all the four sampling stations have exceeded the threshold limit set by the International Commission for Radiological Protection (ICRP) of $1 \mathrm{mSv} / \mathrm{yr}$ for public exposure. Thus the community is at risk of exposure to high dose of radiation as a result of the artisanal gold mining activities. The adoption of rigorous regulations and implementation of mining-policies such as the Minerals and Mining Act of 2007 which prohibited the illegal exploration and or exploitation of Minerals will play the right role in reducing radiation emissions and their consequential harm to the community and the state economy.
\end{abstract}

Keywords: gold, mining, radionuclide, exposure, human health

Cite This Article: Sabo A, Sadiq L. S., and Gamba J., "Radiological Assessment of Artisanal Gold Mining Sites in Luku, Niger State, Nigeria.” Journal of Environment Pollution and Human Health, vol. 6, no. 2 (2018): 45-50. doi: 10.12691/jephh-6-2-1.

\section{Introduction}

Mining refers to the process of extraction of mineral deposits either from the surface or beneath the surface of the earth. Mining is normally carried out where minerals are present in commercial quantity [1]. Nigeria is richly endowed with vast solid mineral resources that are widely distributed throughout the country. So far the Nigerian government has identified 37 mineral deposits in commercial quantity distributed across all the states [2]. As a result of this, mining is done virtually in all the states of the federation.

Mining industry in Nigeria is considered to be a key driver of economic growth which can potentially lead to higher levels of social and economic wellbeing. This potential is however hampered because the industry is yet to get the attention it deserved from the government. According to the 2014 audit report of the Nigeria Extractive Industries Transparency Initiative, the solid minerals sector contributed only about N55.82 billion to the federal government, accounting for a mere four per cent of the country's total national export earnings for the period. Similarly, the sector is dominated by unskilled artisanal small scale miners [3]. Artisanal small scale mining is an activity that encompasses small, medium, informal, legal and illegal miners who use rudimentary methods and processes to extract mineral resources. In the past few years artisanal mining serves as a source of cash income and therefore of livelihood to the communities where it is being practice.

Luku community in Minna has been a center for mining activities with the discovery of Gold deposits alongside Chalk, Limestone and Brass within the region. The Gold mining has made a significant impact on the socio-economic conditions of people involved directly or indirectly in the sector. These miners are however unskilled, underequipped and have little appreciation of the environment. As reported by [1] the mining activity in Luku has resulted in lot of physical environmental impact such as land degradation, destruction of vegetation, erosion of soils and degrading water quality and soils contamination with potentially toxic elements such as $\mathrm{Pb}$, $\mathrm{As}, \mathrm{Cu}, \mathrm{Zn}, \mathrm{Ni}, \mathrm{Cd}$ and $\mathrm{Hg}$ which could accumulate in plants and animals and pass on to human through the food chain.

Mining activity brings about an increase in the levels of Naturally Occurring Radioactive Materials (NORMs) on the earth surface posing serious health risk to humans when inhaled or ingested [4]. More human evidence of the harmful nature of ionizing radiation was also reported by early radiologists and persons working in the Radium industry. Both empirical observations and epidemiological studies have consistently shown carcinogenic properties of ionizing radiation. Survivors of the Hiroshima atomic bomb exposed to radiation above one Sievert showed a significant increase in the incidence of leukemia [5] 
Natural radioactivity is widely spread in the earth's environment and depends primarily on the geological and geographical conditions, and appears at different levels in the soils of each region in the world [6]. According to [7] radionuclides of Uranium and Thorium and their decay products are the most important NORMs in radiological studies as they contribute in no small measure to human exposure in the environment.

Nigeria is such a country where the impact of ionizing radiation has received less attention and concern. Thus, the risk of exposure to radiation is often ignored [8]. As such, although there were reports on the general environmental impacts of the gold mining at Luku community, there is limited scientific information on the background ionizing radiation in the area. Thus, a radiological hazard assessment was carried out in order to evaluate the health risk to the population in the mining area. The study is therefore expected to create awareness to all the stakeholders including (artisanal) miners, the local population, as well as the relevant regulatory authorities on the possible impacts of the mining operation on human health.

\section{Materials and Methods}

\subsection{Study Area and Its Geology}

The study was conducted at Lukku mining site, Minna Niger State. It is located in North-Central part of Nigeria which lies within the coordinates of longitude $6^{0} 25^{\prime} \mathrm{E}$ and $6^{0} 45^{\prime} \mathrm{E}$ and latitude $9^{0} 24^{\prime} \mathrm{N}$ and $9^{0} 48^{\prime} \mathrm{N}$ (Figure 1 and Figure 2) The Minna area comprises of meta-sedimentary and meta-igneous rocks which have undergone polyphase deformation and metamorphism. These rocks have been intruded by granitic rocks of Pan-African age. Five lithostratigraphic units have been recognized in Minna area. The schist occurs as a flat laying narrow southwestnortheast belt at the central part of Minna with small quartzite ridge parallel to it. The gneiss occurs as a small suite at the northern and southern part of the area forming a contact with the granite. Feldspathic rich pegmatite is bounded to the east, with average width of 65 meters and 100 meters long. Granitic rocks dominate the rock types in the area and vary in texture and composition [9]. A study carried out by [10] has shown that higher radiation levels are associated with igneous rock such as granite, earlier described as the dominant rock in the study area.

\subsection{Survey Instrument}

A Radiation Inspector Alert ( $\mathrm{EXP}^{+}$model) as shown on Plate 1 was used for the overall measurement of the radiation levels within the study area that included cumulative radiation and points of measurement at the location. The Inspector uses a Geiger-Mueller tube to detect the total radiation (sum of alpha, beta, gamma, and $\mathrm{x}$-ray radiation). The Geiger tube generates a pulse of electrical current each time radiation passes through the tube and causes ionization. Each pulse is electronically detected and registered as a count. The Inspector displays the counts in the $\mu \mathrm{Sv} / \mathrm{hr}$ units. The device was held with the window facing the surface of the mining site in order to measure the ambient radiation, and the readings were taken after the counts stabilized. The device was ensured to have been calibrated.

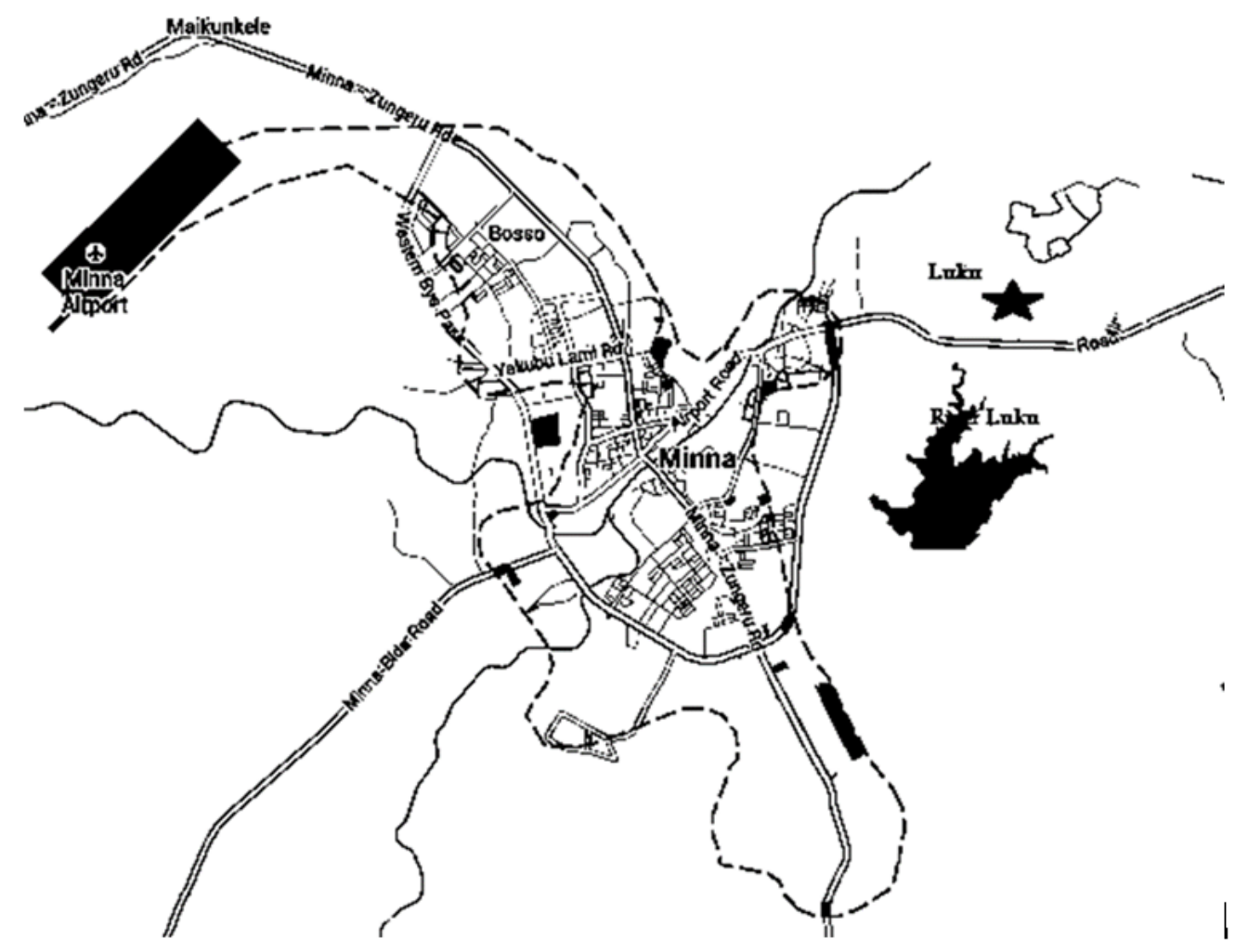

Luku mining site

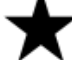

Main road

Figure 1. Map of Minna showing Luku mining site 


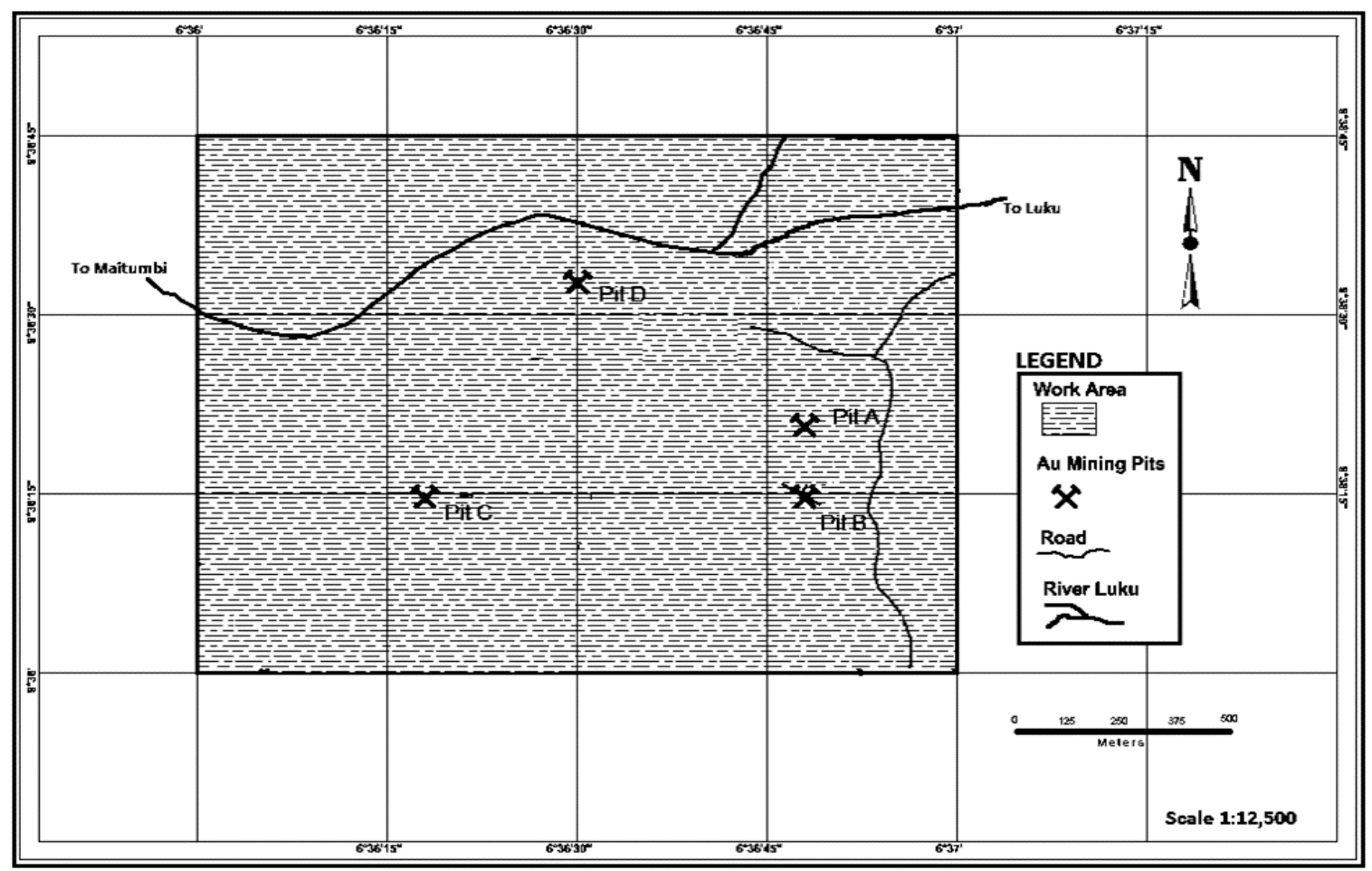

Figure 2. Map of the mining site showing the sampling locations

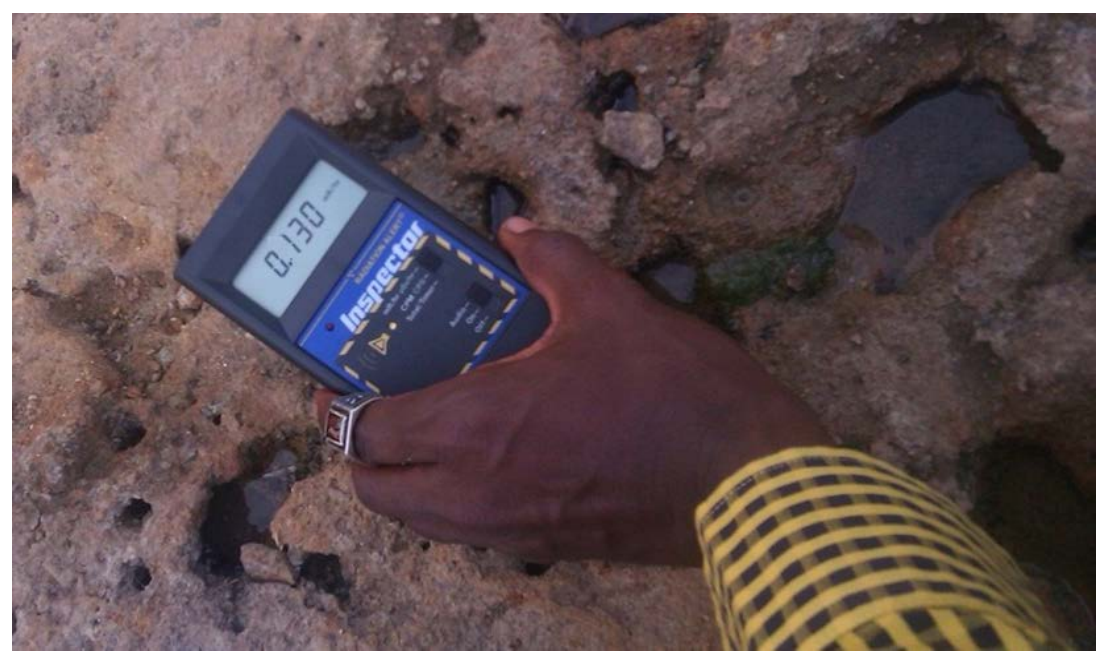

Plate 1. Radiation detector equipment put to use on-site

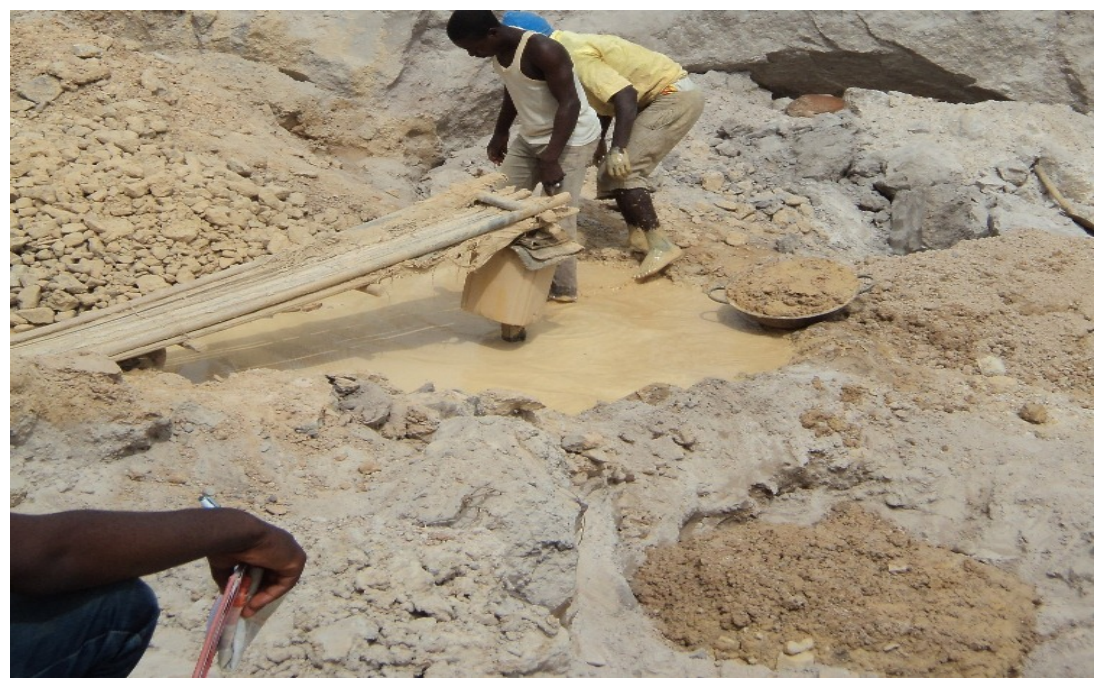

Plate 2. Exposed Luku artisanal Gold miners without protective gears 


\subsection{Method of Data Collection}

Four sampling stations representing different gold excavation pits were identified in the study area. In each of the stations five sampling points were marked. Levels of radiation were recorded at each of the sampling points with 3 replications. Thus a total of 60 readings were taken from the survey area.

Additionally, background reading was taken at a distance of 1000 meters each from the survey pits which was used for correcting the results obtained. In each case, the Radiation Inspector Alert was held at height 1 meter above the ground for the minimum of 30 seconds or until the reading stabilizes, which was converted to annual cumulative dose rate.

\subsection{Data Analysis}

Variables were measured in nominal scales and plotted on the graphs of Cumulative Radiation Level against Points of Measurement. The mean Radiation Levels were therefore plotted against the four survey stations (pits A, B, C and D). All values ( $\mu \mathrm{Sv} / \mathrm{hr}$ ) were converted into $\mathrm{mSv} / \mathrm{yr}$ based on the dose conversion factors of United Nations Scientific Committee on the Effects of Atomic Radiation, [6] using the relation below:

$$
\begin{aligned}
& \text { Cumulative radiation level } \\
& =\frac{m(\mu \mathrm{Sv} / \mathrm{hr}) \times 8760 \mathrm{hrs}}{1000} \mathrm{mSv} / \mathrm{yr}
\end{aligned}
$$

Where $m$ is the INSPECTOR $\mathrm{EXP}^{+}$meter reading.

Then the mean of the readings taken from each of the pit was calculated using the formula;

$$
\bar{x}=\frac{\sum x}{n} .
$$

\section{Results}

\subsection{Radiation Levels of Station A}

Figure 3 shows the mean radiation levels of the pits at Station A. The highest radiation was recorded from the first point of measurement (1) with mean value of $2.41 \mathrm{mSv} / \mathrm{yr}$ followed by $2.12 \mathrm{mSv} / \mathrm{yr}$ at the fourth point (4). The least background radiation recorded was from point 2 with $1.06 \mathrm{mSv} / \mathrm{yr}$. The results showed that all the radiation recorded at station $\mathrm{A}$ exceeded the threshold limit for public exposure to background radiation of $1 \mathrm{mSv} / \mathrm{yr}$ recommended by the International Commission of Radiological Protection [10].

\subsection{Radiation Levels at Station B}

Figure 4 presents the radiation levels of the pits at Station B. The results showed that the second (2) and first (1) points of measurement with mean values of $2.56 \mathrm{mSv} / \mathrm{yr}$ and $2.27 \mathrm{mSv} / \mathrm{yr}$ respectively had the highest levels of radiation.

The least mean value was obtained at the fourth (4) point with $0.74 \mathrm{mSv} / \mathrm{yr}$. Almost same values were recorded from the third (3) and fifth (5) points of measurement with $1.09 \mathrm{mSv} / \mathrm{yr}$ and $1.06 \mathrm{mSv} / \mathrm{yr}$ mean radiation levels respectively.

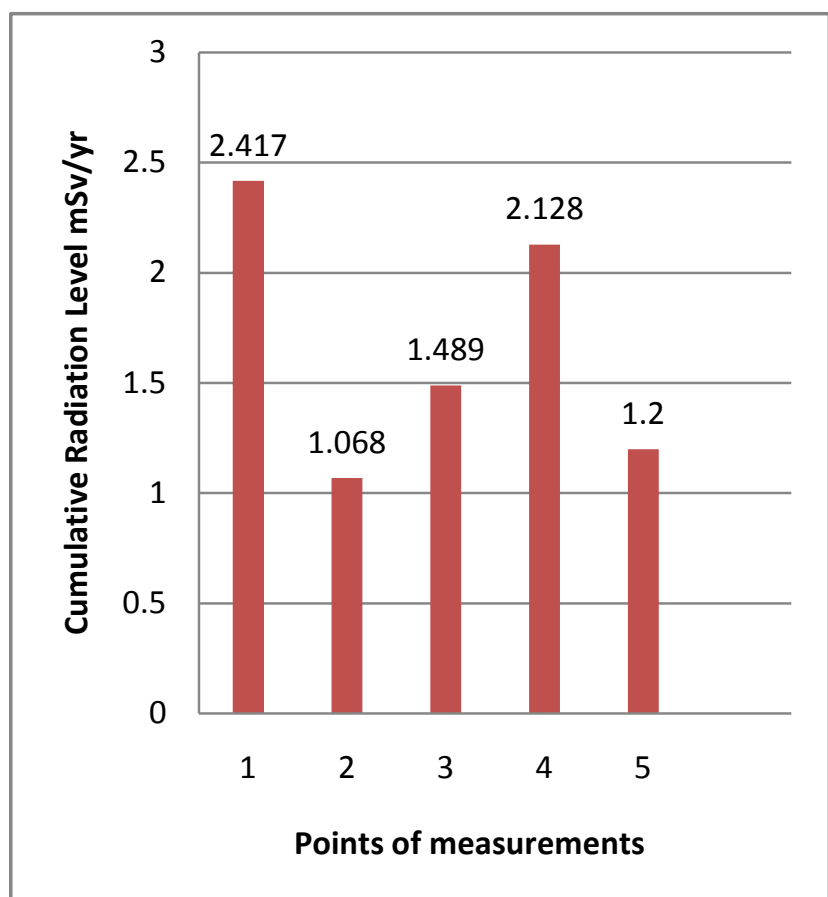

Figure 3. Cumulative radiation levels against points of measurement at Station A

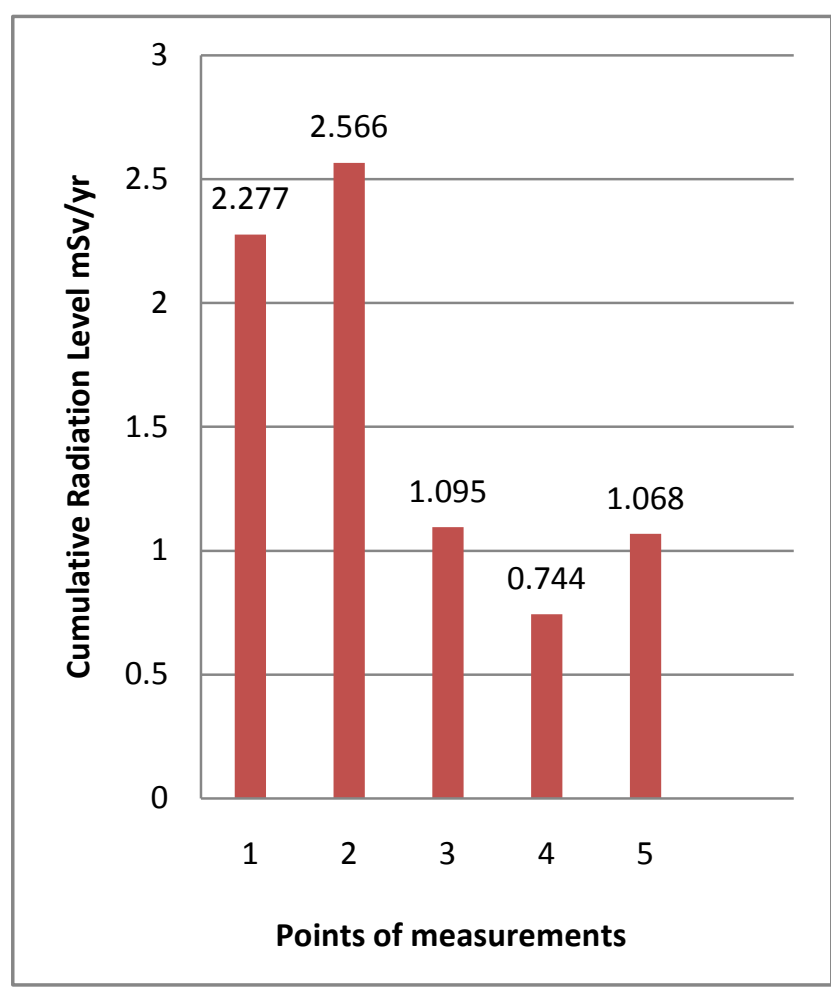

Figure 4. Cumulative radiation levels against points of measurement at Station B

\subsection{Radiation Levels at Station C}

The levels of radiation at different sampling pits at Station $C$ are shown in Figure 5. The investigation revealed that the highest radiation was recorded from Fourth point of measurement with $2.11 \mathrm{mSv} / \mathrm{yr}$. The second and fifth points of measurement recorded the least background radiation levels of $1.2 \mathrm{mSv} / \mathrm{yr}$ each. The first point of measurement had $1.75 \mathrm{mSv} / \mathrm{yr}$, while the third point had $1.14 \mathrm{mSv} / \mathrm{yr}$ background value. 


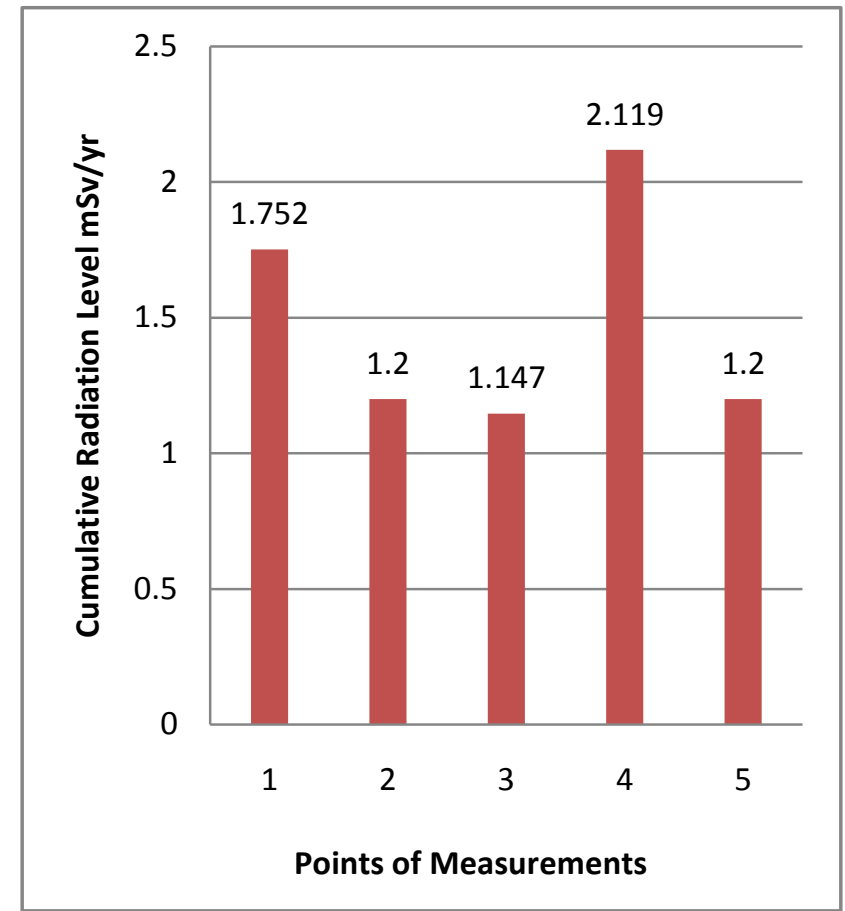

Figure 5. Cumulative radiation levels against points of measurement at Station C

\subsection{Radiation Level of Station D}

The radiation levels recorded in the pits at Station $\mathrm{D}$ are presented in Figure 6. The results showed that $3.39 \mathrm{mSv} / \mathrm{yr}$ was the highest mean value recorded, from the first (1) point of measurement. The mean values observed at the second and fourth points were $2.33 \mathrm{mSv} / \mathrm{yr}$ and $2.12 \mathrm{mSv} / \mathrm{yr}$ respectively. The least levels of radiation were however recorded at points three (3) and Five (5) with $1.48 \mathrm{mSv} / \mathrm{yr}$ and $1.25 \mathrm{mSv} / \mathrm{yr}$ mean values respectively.

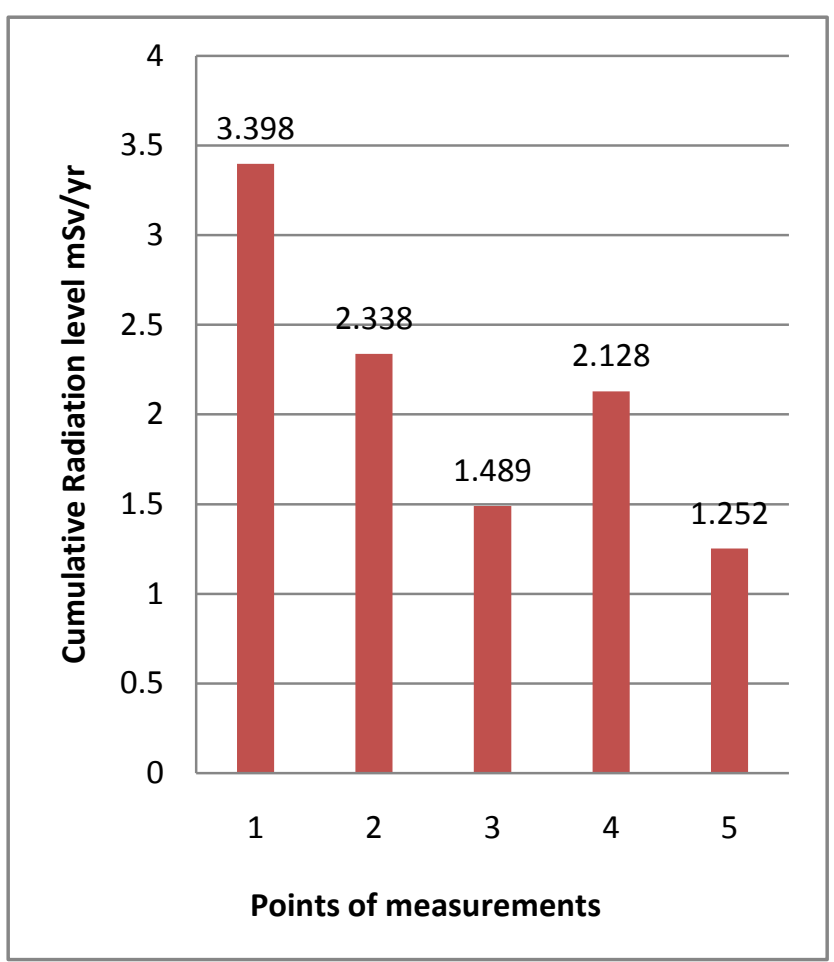

Figure 6. Cumulative radiation levels against points of measurement at Station D

\subsection{Mean Radiation Levels from All the Survey Stations}

Figure 7 shows the mean radiation levels recorded from all the four survey Stations. The results revealed that the highest mean background radiation level was recorded at Station D with mean value of $2.12 \mathrm{mSv} / \mathrm{yr}$. Pits A, B and C however recorded similar but relatively lower background radiation levels of $1.66 \mathrm{mSv} / \mathrm{yr}$., $1.55 \mathrm{mSv} / \mathrm{yr}$. and $1.49 \mathrm{mSv}$ respectively.

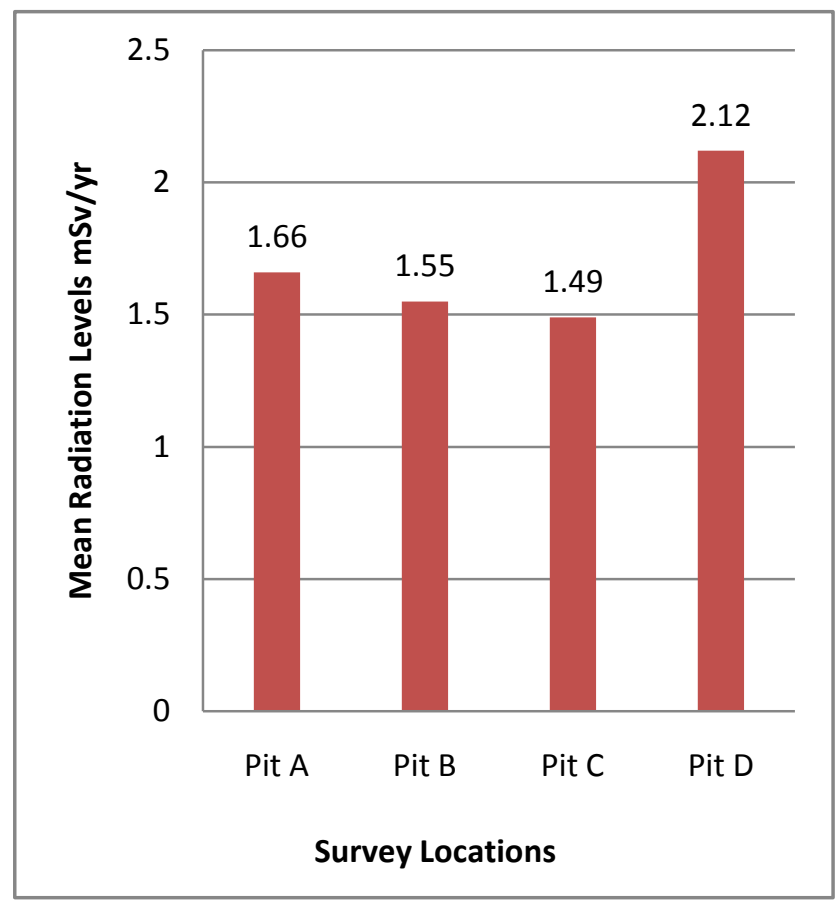

Figure 7. Mean radiation levels against survey locations

\section{Discussion}

Results obtained from the radiological survey revealed that artisanal mining activities have contaminated the environment with radioactive elements and the background radiation recorded in the area was above the acceptable limit of $1 \mathrm{mSv} / \mathrm{yr}$ for public exposure recommended by [11] The investigation revealed that among in all the survey area, sampling point 1 of Station D had the highest emission rate of $3.398 \mathrm{mSv} / \mathrm{yr}$ exceeding the threshold level for public exposure as recommended by ICRP while sampling point 4 of Station $B$ had the least emission rate of $0.744 \mathrm{mSv} / \mathrm{yr}$. However, an average of $0.177 \mathrm{mSv} / \mathrm{yr}$ background radiation was detected at the control area of 1000 meters distance, away from the mined sites which was below the ICPR threshold level.

The most excavated pit (Pit D) appears to present the highest radiation recorded with $3.398 \mathrm{mSv} / \mathrm{yr}$, as well as the highest mean radiation of the four survey stations with $2.12 \mathrm{mSv} / \mathrm{yr}$. The study reveals that mining related practices in Minna poses a threat of possible radiation exposure, especially for the miners and the communities residing by the mining sites.

This study is in conformity with that of [13], conducted in South-Western Nigeria, where they found mean activity concentrations of ${ }^{238} \mathrm{U}$ and ${ }^{40} \mathrm{~K}$ in the mining sites higher 
than the world average. Additionally, assessment of radiation hazard associated with exposure to NORMs from gold mining tailings in the province of Gauteng, South Africa revealed activity concentrations that exceeded the safe limit [13]. The radiological hazard index calculated in the present work is high presenting a potential hazard to the people residing in the gold mining area.

\section{Conclusion}

The results showed that the background radiation recorded have exceeded the threshold limit for public exposure as set by [11]. Therefore, the radiation emanating from the mining site has the potentials of inducing either stochastic or non-stochastic effect of radiation exposure. The results obtained has established baseline information on natural radioactivity in Luku mining site of Minna, Niger State which can be used as a reference data for future work in the area. The adoption of rigorous regulations and implementation of mining-policies such as the Minerals and Mining Act of 2007 which prohibited the illegal exploration and or exploitation of Minerals will play the right role in reducing radiation emissions and their consequential harm to the community and the state economy.

\section{References}

[1] Ako T. A., Onoduku U. S., Oke S. A., Adamu I. A., Ali S. E., Mamodu A., and Ibrahim A. T., Environmental Impact of Artisanal Gold Mining in Luku, Minna, Niger State, North Central Nigeria. Journal of Geosciences and Geomatics, (2)1 28-37. 2014.
[2] Alison-Madueke, D. Opportunities in Nigeria's Minerals Sector. Ministry of Mines and Steel Development, Abuja, Nigeria, 22nd April 2009.

[3] Chineme, O. T., Towards a New Approach to Solid Minerals Mining in Nigeria. THISDAY Newspaper report, $12^{\text {th }}$ November, 2017

[4] Rowland R.E. Low-level radium retention by the human body: A modification of the ICRP publication 20 retention equation. Health Phys. 65: 507-513 1993.

[5] USFDA (United States Food and Drug Administration) Biological Effects of Ionizing Radiation; HEW Publication (FDA): Silver Spring, MD, USA, pp. 77-8004, 2006.

[6] UNSCEAR, United Nations Scientific Committee for Effects of Atomic Radiation. Ionizing Radiation: Sources and Effects. 44-89, 2008.

[7] Ziajahromi S., Khanizadeh M., Nejadkoorki F. Using the RESRAD code to assess human exposure risk to ${ }^{226} \mathrm{Ra},{ }^{232} \mathrm{Th}$, and ${ }^{40} \mathrm{~K}$ in soil. Human Ecol. Risk Assess. 21(1). 2014.

[8] Jwanbot, D.I; Izam, M.M; Nyam, G.G and Dakon, R.J Environmental Ionizing Radiation Distribution Profile in Jos and Environments. Journal of Environment and Earth Science 3(3):87. 2013.

[9] Alabi, A. A. (2011). Geology and environmental impact assessment and benefit of granitic rocks of Minna area, Northwestern Nigeria. Ethiopian Journal of Environmental Studies andManagement, 4 (4).

[10] Sadiq, A. A., \& Agba, E. H. Indoor and outdoor ambient radiation levels in Keffi, Nigeria. Facta universitatis-series: Working and Living Enviromental Protection, 9(1), 19-26. 2012.

[11] ICRP (International Commission of Radiological Protection). ICRP Publication 103. The 2007 Recommendations of the International Commission of Radiological Protection. Ann. ICRP 2008, 32, 2-4.

[12] Ademola, A. K., Bello, A. K., \& Adejumobi, A. C.. Determination of natural radioactivity and hazard in soil samples in and around gold mining area in Itagunmodi, south-western, Nigeria. Journal of Radiation Research and Applied Sciences, 7(3), 249-255 2014.

[13] Caspah, K., Manny, M. and Morgan, M. An Assessment of Radiological Hazards from Gold Mine Tailings in the Province of Gauteng in South Africa Int J Environ Res Public Health. 13(1): 138, 2016. 